\title{
Asbestos content of lung tissue in asbestos associated diseases: a study of 110 cases
}

\author{
VL ROGGLI, ${ }^{1}$ PC PRATT, ${ }^{1}$ AND AR BRODY ${ }^{2}$ \\ From the Department of Pathology, ${ }^{1}$ Duke University and Durham Veterans Administration Medical Centers, \\ Durham, North Carolina 27710, and Laboratory of Pulmonary Pathobiology, ${ }^{2}$ National Institute of \\ Environmental Health Sciences, Research Triangle Park, NC 27709, USA
}

ABSTRACT Diseases associated with asbestos exposure include asbestosis, malignant mesothelioma, carcinoma of the lung, and parietal pleural plaques. In this study the asbestos content of lung tissue was examined in groups of cases representing each of these diseases and in several cases with non-occupational idiopathic pulmonary fibrosis. Asbestos bodies (AB), which are the hallmark of asbestos exposure, were present in the lungs of virtually everyone in the general population and present at increased levels in individuals with asbestos associated diseases. The highest numbers of AB occurred in individuals with asbestosis, all of whom had levels $\geqslant 2000 \mathrm{ABs} / \mathrm{g}$ wet lung tissue. Every case with a content of $100000 \mathrm{ABs} / \mathrm{g}$ or higher had asbestosis. Intermediate levels occurred in individuals with malignant mesothelioma and the lowest levels in patients with parietal pleural plaques. There was no overlap between the asbestos content of lung tissue from patients with asbestosis and those with idiopathic pulmonary fibrosis. Lung cancer was present in half the patients with asbestosis, and the distribution of histological patterns did not differ from that in patients with lung cancer without asbestosis. The asbestos body content in patients with lung cancer was highly variable. Control cases had values within our previously established normal range (0-20 ABs/g). There was a significant correlation $(p<0.001)$ between $A B$ counted by light microscopy and $A B$ and uncoated fibres counted by scanning electron microscopy. The previous observation that the vast majority of asbestos bodies isolated from human tissues have an amphibole core was confirmed.

Asbestos exposure has been associated with several diseases, including asbestosis, mesothelioma of the pleura and peritoneum, lung carcinoma, and parietal pleural plaques. ${ }^{1-3}$ Asbestos bodies, the hallmark of exposure to asbestos, are formed by the coating of partially phagocytosed asbestos fibres with an iron protein mucopolysaccharide complex. ${ }^{4}$ When sufficiently sensitive digestion techniques are used, these structures may be extracted from the lung tissue of virtually every adult in industrialised nations, indicating low level contamination of the environment. ${ }^{5-10}$ Only a portion of the asbestos fibres within the lung are coated, however, so that studies of the correlation between the asbestos content of lung tissue and various asbestos associated diseases require determination of both the coated and uncoated fibre content of the lung using quantitative techniques.

In the present study the asbestos concentration of lung tissue from 110 cases of asbestos associated diseases was examined to attempt to correlate lung asbes-

Accepted 2 April 1985 tos burdens with specific pathological changes. Furthermore, the asbestos concentrations within the lung were compared with the occupational exposure history so that, in cases where exposure was unknown or unavailable, an assessment could be made regarding an approximate level of exposure-for example, environmental $v$ low level occupational $v$ long term occupational. In addition, the relation between the asbestos body concentration estimated by light microscopy (LM) and the type and numbers of coated and uncoated fibres observed by scanning electron microscopy (SEM) was studied. Such a comparison should provide information on the comparability of $N$ asbestos body counts using different analytical tech- $N$ niques, and the relation between asbestos bodies and total fibre or uncoated fibre counts as well as the types of fibres present.

Materials and methods

PATIENTS

The study group included all cases of asbestosis, $\frac{O}{\Phi}$ mesothelioma, parietal pleural plaques, and lung can- 
cer with a suspected asbestos aetiology seen at Duke University Medical Center or Durham Veterans Administration Medical Center (57 cases) or referred in consultation to one of the authors (VLR, 53 cases) from July 1980 to April 1984 . To be included in the study, tissue had to be available for determination of asbestos content. Thirty cases of asbestosis were included in the study, defined histologically as the presence in tissue sections of both asbestos bodies and peribronchiolar fibrosis, with or without fibrosis of the alveolar septa and with or without honeycombing. ${ }^{11}$ The severity of asbestosis was judged histologically using a previously reported grading scheme $^{11}$ that takes into account both the proportion of bronchioles affected and the severity of the disease. Nineteen cases of diffuse (malignant) mesothelioma were studied, the diagnosis being based on the gross distribution of tumour, typical histological pattern, and the absence of any other primary site. ${ }^{112}$ Eighteen of these cases were confirmed at necropsy. Forty eight cases of parietal pleural plaques without asbestosis were examined, plaques being defined as ivory coloured, circumscribed foci of pleural thickening, with or without calcification, most often affecting the posterolateral chest wall and domes of the diaphragm, and exhibiting microscopic features of layers of almost acellular hyalinised collagen. ${ }^{11314}$ Finally, there were 17 cases of primary lung carcinomas with neither plaques nor asbestosis. These were classified histologically according to the criteria proposed by the World Health Organisation. ${ }^{15}$

A "control" group included 10 cases with idiopathic pulmonary fibrosis (cryptogenic fibrosing alveolitis) and 10 cases with normal lungs. Idiopathic pulmonary fibrosis (IPF) was defined as diffuse bilateral interstitial fibrosis with varying degrees of inflammation for which there was no apparent aetiology. These cases were diagnosed by open lung biopsy ( 5 cases) or necropsy ( 5 cases). Asbestos bodies were not seen in tissue sections, and there was no evidence of pleural plaques. In the 10 cases with normal lungs no fibrosis, emphysema, or consolidation, and minimal pigmentation, was evident on gross inspection at necropsy.

Occupational information and smoking history were obtained by a review of the medical records without prior knowledge of the asbestos content of the lung tissue. The age and sex of each patient were also recorded.

\section{TISSUE DIGESTION TECHNIQUE}

Asbestos was recovered from the lung by digesting the tissue in $5.25 \%$ sodium hypochlorite solution as previously described. ${ }^{16} \mathrm{~A}$ sample weighing $4 \cdot 5-5 \cdot 5 \mathrm{~g}$ was selected (one to four samples a case, depending on tissue availability), blotted briefly on a paper towel, and minced with a clean scalpel blade. After digestion was complete and the contents allowed to settle for at least 72 hours, the supernatant was carefully pipetted and the sediment suspended in $40 \mathrm{ml}$ of a $1: 1(\mathrm{v} / \mathrm{v})$ mixture of chloroform and $50 \%$ ethanol. The suspension was centrifuged at $10000 \mathrm{rpm}$ for 30 minutes, the supernatant discarded, and the sediment suspended in $95 \%$ ethanol. The sediment was then collected on a Nuclepore filter (pore size $0.4 \mu \mathrm{m}$ ) that was mounted on a glass slide for asbestos body quantification by LM.

This method works well for asbestos bodies and larger uncoated amphibole fibres but studies in our laboratory, using a rat model of chrysotile inhalation exposure, indicated that a variable and sometimes substantial proportion of small chrysotile fibres are lost during the centrifugation step at the chloroformethanol interface (unpublished observations). Furthermore, the use of large sample sizes in patients with heavy asbestos exposure results in filters that are unusable because of large accumulations of fibres. Therefore, we devised a hypochlorite digestion tech-

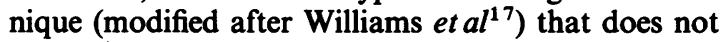
require centrifugation, permits quantitative recovery of chrysotile asbestos fibres, and is suitable for smaller sample sizes $\left(0 \cdot 1-0.4 \mathrm{~g}\right.$ wet weight) ${ }^{18}$ Organic residues are minimised with this technique by successive rinsing of the filter with oxidising agents (8.0\% oxalic acid, $5 \cdot 25 \%$ sodium hypochlorite). In most cases, before the samples were digested, tissue sections were screened for asbestos body content. In cases where asbestos bodies were absent or infrequent, the technique using centrifugation and a large tissue sample $(4.5-5.5 \mathrm{~g})$ was used to determine the asbestos body content. In cases where asbestos bodies were numerous or the tissue sample was limited $(<1 \mathrm{~g})$, the technique not requiring centrifugation ${ }^{18}$ was used; it was always used for SEM studies. Both techniques give comparable results for quantification of asbestos bodies by LM. In 10 cases for which both techniques were used the mean ratio of asbestos body counts by the centrifugation technique to that by the noncentrifugation technique was $1 \cdot 10$ (range, $0 \cdot 31-3.53$ ).

In 21 cases wet fixed tissue was not available and it was necessary to digest tissue recovered from a paraffin block. The blocks were deparaffinised in xylene and then rehydrated to $95 \%$ ethanol, from which a wet weight was obtained. Since a portion of tissue that has been dehydrated through a series of lipid solvents will weigh less than its formalin fixed wet weight, it was necessary to determine a conversion factor so that the asbestos counts on tissue obtained from paraffin blocks would be comparable to those obtained from wet fixed tissue. We determined that, on average, a deparaffinised lung section rehydrated to $95 \%$ ethanol weighs $70 \%$ as much as the same 
formalin fixed section before paraffin embedding. Therefore, all asbestos body and fibre counts from tissues recovered from paraffin blocks were multiplied by a factor of $0 \cdot 70$.

\section{ASBESTOS QUANTIFICATION}

Asbestos bodies were counted on Nuclepore filters by LM at a magnification of $\times 200$, and the results expressed as asbestos bodies per gram of wet lung tissue. Only bodies with typical dumbbell, javelin, or segmented morphologies and thin transparent cores were included in the counts. ${ }^{4}$ Non-asbestos ferruginous bodies (pseudoasbestos bodies) ${ }^{19}$ with broad yellow cores or dark brown to black cores were frequently encountered but were not included in the calculations. In most cases they were far less numerous than the true asbestos bodies. The analytical sensitivity of the technique is one asbestos body per filter, with a detection limit of 0.2 asbestos bodies per gram of wet lung tissue.

Analytical SEM with asbestos fibre identification and enumeration was performed in 59 cases. The Nuclepore filter was mounted on a carbon disc with colloidal graphite, sputter coated with gold, and examined in a SEM (JEOL type JSM35) equipped with a Kevex energy dispersive spectrometer at a magnification of $\times 1000$. This magnification was selected because it is low enough to detect the entire range of asbestos body sizes, yet high enough to identify the vast majority of fibres $5 \mu \mathrm{m}$ or greater in length. Coated and uncoated fibres were counted separately. All the fibres whose centres fell within sequential fields were counted until a total of 200 fibres or 100 fields (whichever came first) were encountered. The total number of coated and uncoated fibres on the filter could then be calculated, and the results expressed per gram of lung tissue. The analytical sensitivity is 125 fibres a filter, with a theoretical detection limit of 400 fibres a gram for a 0.3 gram tissue sample. Samples were examined at $0^{\circ}$ tilt, with a constant working distance of $15 \mathrm{~mm}$ between the specimen and the objective lens.

In each case examined by SEM 10-20 fibres were analysed by energy dispersive $x$ ray analysis to determine the types of fibres present. Consecutive fibres and asbestos bodies with sufficiently exposed cores to permit analysis were identified at $\times 1500$ magnification and analysed using the spot mode at $20 \mathrm{kV}$ accelerating voltage and acquisition time of $10-100 \mathrm{sec}$ (average $60 \mathrm{sec}$ ). Chrysotile was recognised by its often curly morphology, small diameter, and elemental content of $\mathrm{Mg}$ and $\mathrm{Si}$ only. The amphiboles were straight fibres, sometimes with longitudinal grooves, diameters somewhat greater than chrysotile, and distinctive chemical compositions (fig 1). The chemical compositions of unknown fibres were com- pared with samples prepared from the UICC asbestos $\frac{\mathbb{D}}{\mathbb{Q}}$ standards (kindly provided by Dr V Timbrell, MRC Pneumoconiosis Unit, Penarth, Cardiff, United King- $\frac{\overrightarrow{\bar{S}}}{\vec{\partial}}$ dom).

STATISTICAL METHODS

The relation between histological grade of asbestosis $\vec{\nabla}$ and the asbestos concentration in lung tissue, smoking 2 history, age, duration of asbestos exposure, and क uncoated to coated fibre ratio was examined by linear $\overrightarrow{0}$ regression analysis and determination of the cor- $\overrightarrow{-}$ relation coefficient $\mathbf{r}$. This method was also used to $\vec{\omega}$ examine the relation between dimensions of pleural $\stackrel{\circ}{\circ}$ plaques and asbestos body content, asbestos body $\frac{\mathbb{}}{3}$ counts by LM as compared with SEM, and coated $v$. uncoated fibre counts by SEM. Non-parametric $\omega$ analysis (Wilcoxon signed rank test) was used to compare the asbestos content of the lung in patients with $\infty$ asbestosis with and without lung cancer. Results were accepted as statistically significant when $\mathrm{p}<0.05$.

\section{Results}

NORMAL LUNGS

Occupational information for the 10 patients with $\stackrel{\oplus}{\mathscr{E}}$ normal lungs at necropsy is given in table 1 and the asbestos body concentrations for these cases summarised in table 2 . These values compare well with our previously established normal range of $0-20$ o $\mathrm{ABs} / \mathrm{gm} .{ }^{1216}$

\section{ASBESTOSIS}

All 30 patients with asbestosis were men, with a mean age of $60.6 \pm 9 \cdot 1$ years. Occupational information was available for 29 (table 1) and all had worked directly with asbestos or asbestos containing products for periods ranging from five to 44 years (mean $27.5 \frac{\mathbb{D}}{3}$ years). Smoking history was available for 26: all were smokers or ex-smokers (one smoked cigars only). Four had malignant mesothelioma (3 pleural, 1 peritoneal) and 15 had carcinoma of the lung (see below). 3

Table 2 shows the asbestos content of the lung tissue in these 30 cases. All patients had at least 2000 asbestos bodies per gram of wet lung (ABs/g), with a $\frac{7}{0}$ median concentration exceeding $100000 \mathrm{ABs} / \mathrm{g}$. In every patient with 100000 or more $\mathrm{ABs} / \mathrm{g}$ checked by $\mathrm{N}$ LM, asbestosis was confirmed histologically. Simi- N larly, every patient with 500000 or more uncoated $N$ fibres greater than or equal to $5 \mu \mathrm{m}$ in length had $\omega$ asbestosis. There was no overlap in the asbestos body or uncoated fibre concentrations between asbestosis $\stackrel{0}{=}$ and either idiopathic pulmonary fibrosis cases or normal lungs (table 2).

The relation between the histological grade of asbestosis and the asbestos body count (LM and $\underset{\mathrm{D}}{\mathrm{O}}$ SEM), uncoated fibre count (SEM), and total fibre $\frac{?}{\mathrm{O}}$ 

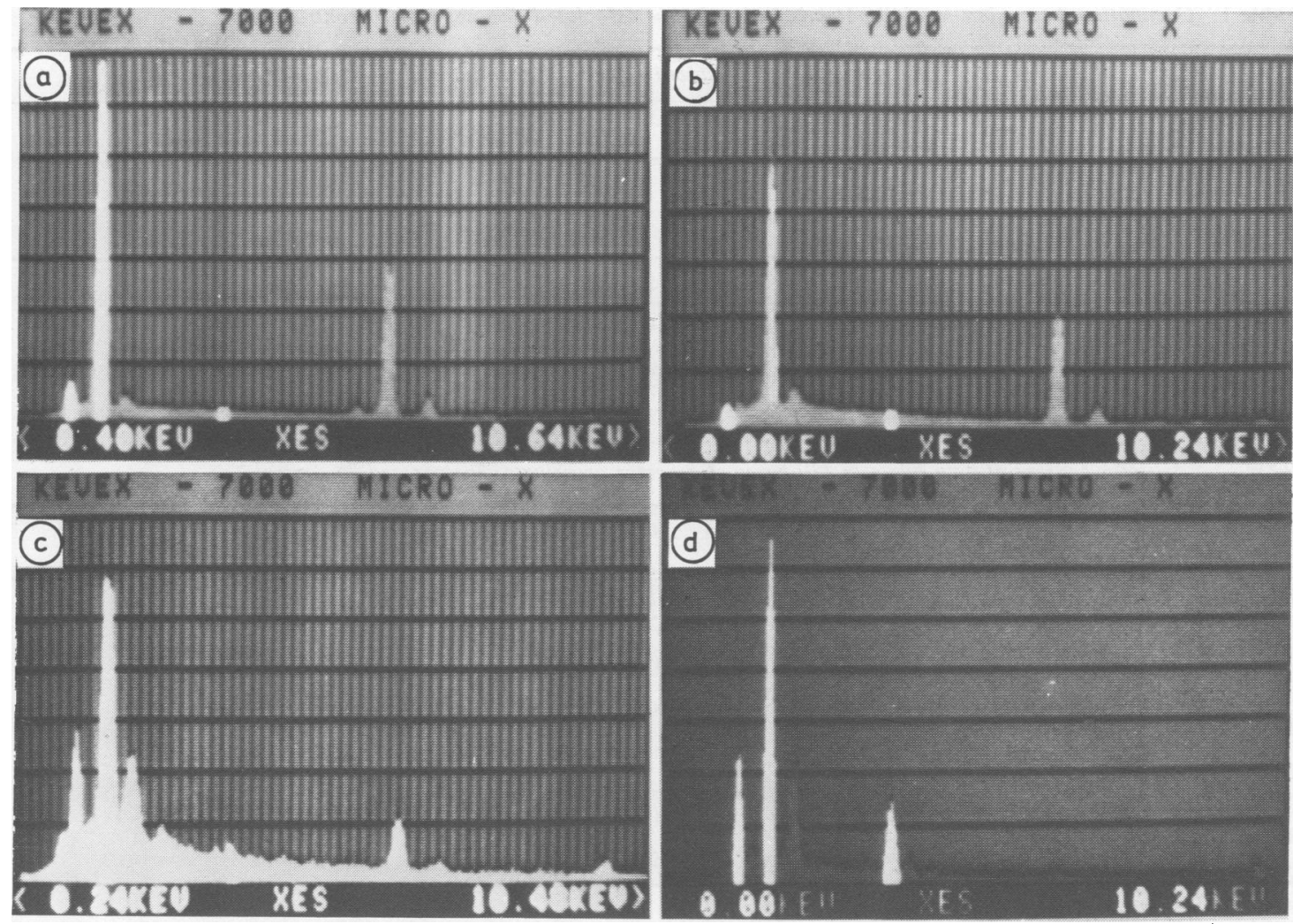

Fig 1 Energy dispersive $x$ ray spectra of four different amphibole asbestos fibres. (a) Amosite has peaks for $\mathrm{Si}, \mathrm{Fe}, \mathrm{Mg}$, and sometimes $\mathrm{Mn}$. (b) Crocidolite has peaks for $\mathrm{Si}, \mathrm{Fe}, \mathrm{Na}$, and $\mathrm{Mg}$. (c) Anthophyllite has peaks for $\mathrm{Si}, \mathrm{Mg}$, and $\mathrm{Fe}$. (d) Tremolite has peaks for $\mathrm{Si}, \mathrm{Mg}$, and $\mathrm{Ca}$. Peak in each spectrum immediately to right of Si is due to Au used to coat specimen.

count (SEM) was examined. When only cases with three or more histological sections of lung were considered, there was a significant $(p<0.05)$ correlation between the grade of asbestosis and each of the four asbestos content parameters. The best correlations were obtained for histological grade of asbestosis $v$ total fibre count by SEM $(\mathrm{r}=0.57)$ and $v$ uncoated fibre count by SEM $(r=0.56$, fig 2$)$. There was no significant correlation between histological grade of asbestosis and uncoated to coated fibre ratio $(r=$ $0.08)$, age $(r=0.15)$, or duration of exposure to asbestos $(r=0.23)$. Interestingly, there was a correlation between histological grade of asbestosis and smoking history by pack-years $(\mathrm{n}=15, \mathrm{r}=0.53, \mathrm{p}<0.05)$.

\section{MESOTHELIOMA}

Nineteen patients (18 men, 1 woman) had mesothelioma, four of whom also had asbestosis as described above. The mean age was $57.8 \pm 11.5$ years. Occupational information was available for all 19 (table 1). Fifteen (including the four with asbestosis) had been exposed to asbestos or asbestos containing products for periods ranging from one to $\mathbf{4 0}$ years (mean 21.0 years). The remaining four were manual labourers (maintenance, heavy machinery operator, construction) and could conceivably have been exposed to asbestos containing materials. Smoking history was available for $14 ; 10$ were smokers or exsmokers. There were 16 pleural and three peritoneal tumours. Among the 16 cases for whom histological sections were available for review, there were three epithelial, six sarcomatous, and seven biphasic (mixed epithelial and sarcomatous) tumours.

Table 2 shows the asbestos content of the lung tissue of the 15 with mesothelioma without asbestosis. The asbestos body counts exceeded our previously established normal range of $0-20 \mathrm{ABs} / \mathrm{g}^{1216}$ in 10 of these cases, nine of whom had a definite occupational exposure to asbestos. In five patients the asbestos body count was within our normal range, alhough 
Table 1 Occupational category for 110 patients with asbestos associated diseases and 20 controls*

\begin{tabular}{|c|c|c|c|c|c|}
\hline & Asbestos insulator & Shipyard worker ${ }^{b}$ & Other asbestos ${ }^{c}$ & Manual labourer & Other ${ }^{e}$ \\
\hline $\begin{array}{l}\text { Asbestosis } \\
\text { Mesothelioma } \\
\text { Parietal pleural plaques } \\
\text { Lung cancer } \\
\text { Idiopathic pulmonary fibrosis } \\
\text { Normal lungs }\end{array}$ & $\begin{array}{r}23 \\
5 \\
4 \\
0 \\
0 \\
0\end{array}$ & $\begin{array}{l}4 \\
3 \\
6 \\
7 \\
0 \\
0\end{array}$ & $\begin{array}{l}2 \\
3 \\
1 \\
2 \\
2 \\
0\end{array}$ & $\begin{array}{r}0 \\
4 \\
15 \\
3 \\
1 \\
1\end{array}$ & $\begin{array}{r}0 \\
0 \\
18 \\
2 \\
6 \\
9\end{array}$ \\
\hline
\end{tabular}

* Occupational information was not available in eight cases and one control (IPF).

Asbestos insulator: insulator, asbestos sprayer, pipefitter, pipecoverer, boiler maker, asbestos sawer, plasterer.

'Shipyard worker: joiner, fitter, shipwright, electrician, welder, draftsman, handyman (excluding asbestos insulator).

'Other asbestos: asbestos cement worker, asbestos textile, brakeline worker, industrial exposure to asbestos not further specified.

'Manual and skilled labourers: construction, electrician, maintenance, painter, logger, foundry worker, heavy machinery operator, plumber, mason.

'Other: textile worker, farmer, military, chemical worker, factory worker, dietician, guard, musician, salesman, barber, engineer, teacher, tailor.

Table 2 Asbestos content of lung tissue in 110 cases of asbestos associated diseases and 20 controls*

\begin{tabular}{|c|c|c|c|c|c|c|}
\hline & No & Age & Smokers ${ }^{d}$ & $\begin{array}{l}\text { Asbestos bodies } / g \\
(L M)\end{array}$ & $\begin{array}{l}\text { Asbestos bodies } / g \\
\text { (SEM) }\end{array}$ & $\begin{array}{l}\text { Uncoated fibres } / g^{e} \\
\left(\times 10^{3}\right)\end{array}$ \\
\hline Asbestosis & 30 & \multirow{4}{*}{$\begin{array}{l}62 \\
(37-79) \\
60 \\
(26-78) \\
62 \\
(36-89) \\
57 \\
(40-74)\end{array}$} & $26 / 26$ & \multirow{4}{*}{$\begin{array}{c}106000 \\
(2400-684000) \\
550 \\
(0 \cdot 2-13300) \\
110 \\
(0 \cdot 6-27500) \\
102 \\
(0.8-46000)\end{array}$} & \multirow{4}{*}{$\begin{array}{l}307000 \\
(24500-1,400000) \\
15800 \\
(0-84200) \\
1700 \\
(900-65000) \\
13900 \\
(450-51000)\end{array}$} & \multirow{4}{*}{$\begin{array}{l}690 \\
(141-12500) \\
67 \\
(1 \cdot 2-413) \\
2 \cdot 2 \\
(0 \cdot 8-243) \\
29 \\
(0 \cdot 7-141)\end{array}$} \\
\hline Mesothelioma" & 15 & & $7 / 11$ & & & \\
\hline Pleural plaques $^{b}$ & 48 & & $32 / 38$ & & & \\
\hline Lung cancer ${ }^{c}$ & 17 & & $16 / 16$ & & & \\
\hline $\begin{array}{l}\text { Idiopathic pulmonary } \\
\text { fibrosis }\end{array}$ & 10 & \multirow{2}{*}{$\begin{array}{l}62 \\
(39-85) \\
64 \\
(28-85)\end{array}$} & $5 / 7$ & $\begin{array}{c}9 \\
(0.8-148)\end{array}$ & \multirow{2}{*}{$\begin{array}{l}{ }^{\dagger}(0-580) \\
\text { ND }\end{array}$} & \multirow{2}{*}{$\begin{array}{l}29 \\
(18-43) \\
\text { ND }\end{array}$} \\
\hline Normal lungs & 10 & & $4 / 10$ & $\begin{array}{c}3 \\
(0 \cdot 2-22)\end{array}$ & & \\
\hline
\end{tabular}

"Patients with mesothelioma without asbestosis.

bPatients with pleural plaque without asbestosis or mesothelioma.

'Patients with lung cancer without asbestosis or pleural plaques.

${ }^{d}$ Number of cases that are smokers/number of cases for which smoking history available.

'Magnification $1000 \times-$ includes mainly fibres $>5 \mu \mathrm{m}$ in length.

*Values reported as median, with range indicated in parentheses underneath.

† Median value below range of detection.

ND = Data unavailable.

one of these was probably exposed to asbestos (brake repairman, $>40$ years). The highest counts were seen in the four patients who also had asbestosis (median count $380000 \mathrm{ABs} / \mathrm{g}$, range $28000-684000 \mathrm{ABs} / \mathrm{g}$ ). SEM was performed in 10 of the 15 patients without asbestosis (table 2). These patients had on average about $10 \%$ as many uncoated fibres per gram as the patients with asbestosis.

\section{PARIETAL PLEURAL PLAQUES}

The 48 patients with parietal pleural plaques had neither asbestosis on histological examination nor mesothelioma. Forty six were men with a mean age of 62.4 \pm 9.4 years. Occupational information was obtained for 44 (table 1). Eleven were exposed to asbestos occupationally, 15 were manual labourers with possible exposure, and 18 had no known exposure to asbestos. Smoking history was available for 38 and 32 were smokers or ex-smokers (including one pipe smoker and one cigar smoker). Plaques were bilateral in 33 patients, unilateral in 12, and of unknown distribution in three. Six had carcinoma of the lung (see below). Twenty five of the 48 cases of plaques included in the present study have been reported previously. ${ }^{13}$

The asbestos body content of the lung tissue of all 48 patients with pleural plaques is summarised in table 2. The asbestos body content exceeded our normal range of 0-20 ABs/g in a greater proportion of the 33 patients with bilateral plaques $(26 / 33$, or $79 \%)$ than $N$ unilateral plaques $(6 / 12$, or $50 \%)$, although this $\mathrm{N}$ difference is not significant. The median count for patients with bilateral plaques was $170 \mathrm{ABs} / \mathrm{g}$ (range 1.2-27500) as compared with $46 \mathrm{ABs} / \mathrm{g}$ (range $\frac{0}{\Phi}$ $0.6-1420$ ) in patients with unilateral plaques. There $\stackrel{\mathcal{Q}}{?}$ was no significant correlation between the asbestos body content of lung parenchyma and the maximum dimension $(n=19, r=0 \cdot 14)$ or the total area $(n=$ $14, r=0.03$ ) of plaque cases for whom this data was 


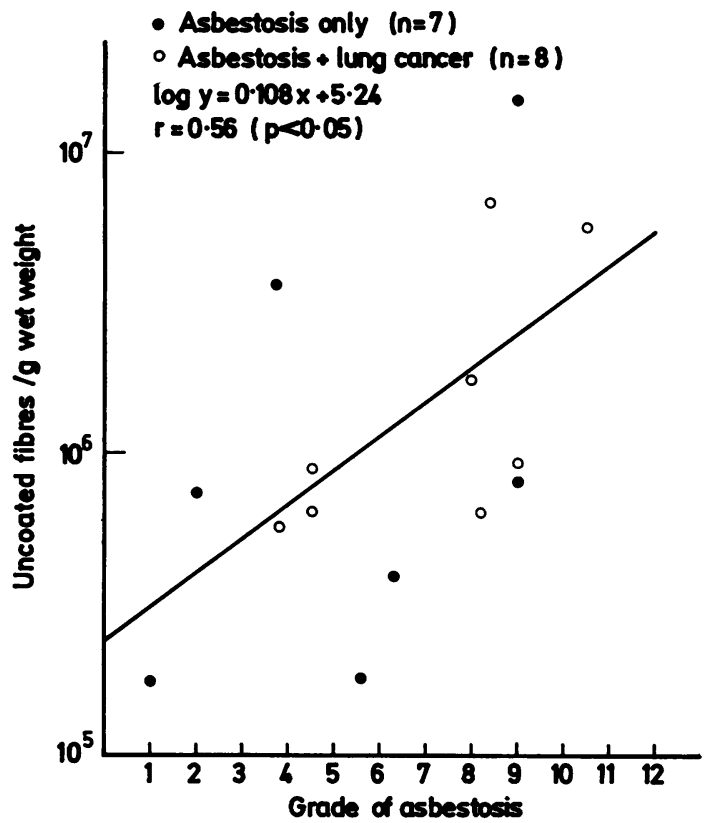

Fig 2 Correlation between uncoated fibre count by scanning electron microscopy and histological assessment of severity of asbestosis using grading scheme of CAP and $N I O S H^{11}$ for 15 cases with asbestosis $(r=0.56$, $p<0.05$ ).

available. SEM was performed in five instances (table 2) and these patients had on average about $3 \%$ as many uncoated fibres per gram as the patients with mesothelioma.

\section{LUNG CANCER}

There were 38 patients with carcinoma of the lung, including 15 with asbestosis, six with pleural plaques, and 17 with neither plaques nor asbestosis. Most of the latter cases were examined for asbestos content of lung tissue because of clinical suspicion of asbestos exposure. There were $37 \mathrm{men}$, and the mean age was $60.8 \pm 9.6$ years. All 15 patients with asbestosis worked directly with asbestos. Of the six patients with plaques (but no asbestosis) and lung cancer, one was an asbestos insulator, two were manual labourers, and three had no known exposure to asbestos. Among the remaining 17 , nine were exposed occupationally to asbestos or asbestos containing products, three were manual labourers, two had no history of exposure to asbestos, and occupational information was unavailable in the remaining three. Smoking history was available in 34 cases; all were smokers or exsmokers (including one pipe smoker and one cigar smoker).
Table 2 shows the asbestos content of the lung tissue for the 17 patients with neither plaques nor asbestosis. The $\mathbf{L M}$ asbestos body concentrations were similar for patients with lung cancer and those with parietal pleural plaques. Asbestos body counts were increased in 12 of the $17(71 \%)$. Nevertheless, SEM studies (performed in 10 cases) yielded median coated and uncoated fibre counts about 10 times higher than in plaque cases, although the range of values is similar (table 2). Table 3 shows the distribution of histological patterns of lung cancer of cases with asbestosis, without asbestosis (but with increased lung asbestos body content), and with normal asbestos body content. There is no apparent trend in the distribution of histological types among these three catagories. Among patients with asbestosis, there was no significant difference in the asbestos body content of lung tissue for those with lung cancer as compared with those without lung cancer $(p=0.74$ by Wilcoxon signed rank test, median values of 118000 and 90000 $\mathrm{ABs} / \mathrm{g}$, respectively).

\section{OTHER NEOPLASIA}

Several tumours other than lung carcinoma were encountered in this study. There were 15 cases of malignancy in this group with other neoplasia, all but one of which had parietal pleural plaques (see above). None had asbestosis histologically. There were four cases with laryngeal carcinoma, five with gastrointestinal carcinoma, and four with haematopoietic malignancies. The gastrointestinal carcinomas included two squamous cell carcinomas of the oesophagus, two adenocarcinomas of the colon, and one rectal adenocarcinoma. One patient with colonic adenocarcinoma had neither plaques nor asbestosis and does not appear in tables 1 or 2 . This 55 year old man had been a shipfitter for 30 years and had 22000 $\mathrm{ABs} / \mathrm{g}$ of lung tissue. The haematopoietic malignancies included one patient with primary pulmonary lymphoma, ${ }^{20}$ one with chronic granulocytic leukaemia, one with nodular poorly differentiated lymphocytic lymphoma, and one with acute myelomonocytic leukaemia. The remaining two patients included one case of hepatoma and one with three malignancies: carcinoma of the lung, prostate, and kidney. The median asbestos body concentration for this group was $380 \mathrm{ABs} / \mathrm{g}$ (range 10-20000 $\mathrm{ABs} / \mathrm{g}$ ), which is greater than the median value for parietal pleural plaque cases as a group (table 2). Among the 14 cases of other neoplasia with plaques, 12 were bilateral and two unilateral.

\section{ASBESTOS BODY CONTENT OF LUNG}

$\checkmark$ OCCUPATIONAL CATEGORY

The highest levels of asbestos body concentration were found in patients whose occupation entailed 
Table 3 Distribution of histological types of lung cancer in individuals with and without asbestosis

\begin{tabular}{llcc}
\hline & Asbestosis & No asbestosis, increased ABs & No asbestosis, normal ABs \\
\hline Squamous cell carcinoma & 6 & 6 & 5 \\
Adenocarcinoma & 4 & 8 & 1 \\
Small cell carcinoma & 4 & 1 & 1 \\
Large cell carcinoma & 0 & 2 & 0 \\
Adenosquamous carcinoma & 1 & 0 & 1 \\
Unknown (tissue unavailable for review) & 1 & 0 & 0 \\
Total & 16 & 17 & 8
\end{tabular}

Multiple tumours in one individual (one case from each column): adenosquamous + small cell carcinoma, squamous + adenocarcinoma, and squamous + small cell carcinoma.

$\mathrm{ABs}=$ Asbestos bodies per gram of wet lung.

direct exposure to asbestos (columns 1-3, table 1). The median asbestos body concentration for these 62 asbestos workers was $10400 \mathrm{ABs} / \mathrm{g}$ (range 2.6-684000 ABs/g), whereas the median values for the 24 manual labourers and 35 individuals with "other" occupations were $10 \mathrm{ABs} / \mathrm{g}$ (range 0.2-4530) and 15 $\mathrm{ABs} / \mathrm{g}$ (range 0.4-3260 ABs/g), respectively. Among the asbestos workers, the highest levels were present in insulators ( 32 cases), with a median asbestos body count of $63000 \mathrm{ABs} / \mathrm{g}$ (range 61-684000 ABs/g).

\section{COMPARISON OF LIGHT MICROSCOPIC AND}

SCANNING ELECTRON MICROSCOPIC STUDIES

The relation of asbestos body counts by LM $v$ SEM in 50 cases is shown in fig 3a. As a result of the higher magnification and superior resolution of the latter, the asbestos body concentrations determined by SEM exceeded the $\mathbf{L M}$ values in $\mathbf{4 4}$ of $\mathbf{5 0}$ cases. The actual ratio of asbestos body counts by LM to SEM varied somewhat from case to case. In some instances asbestos bodies (and fibres) were obscured by organic debris on the filter, reducing the SEM counts relative to the LM counts. In a few cases asbestos bodies were obscured by haemosiderin, reducing the LM counts relative to the SEM counts (the superior resolution of the latter still permitting recognition of asbestos bodies among the haemosiderin particles). Also, cases with sparsely coated fibres tend to have SEM counts that are several fold greater than the LM counts. None the less, the correlation between LM and SEM asbestos body counts is excellent over a wide range of values $(r=0.94, p<0.001)$.

The relation of coated (asbestos body) and uncoated fibre counts by SEM in 51 cases is shown in fig $3 \mathrm{~b}$. This shows that there is an excellent correlation between asbestos body counts and the lung content of uncoated fibres $5 \mu \mathrm{m}$ or greater in length $(\mathrm{r}=0.90, \mathrm{p}$ $<0.001$ ). The uncoated fibre count exceeded the asbestos body count (often by a factor of 10 or greater) in 44 of 51 cases. Variation from case to case seemed to be related most closely to the amount of coating: cases with heavily coated asbestos bodies, obscuring the core fibre, tended to have a lower ratio

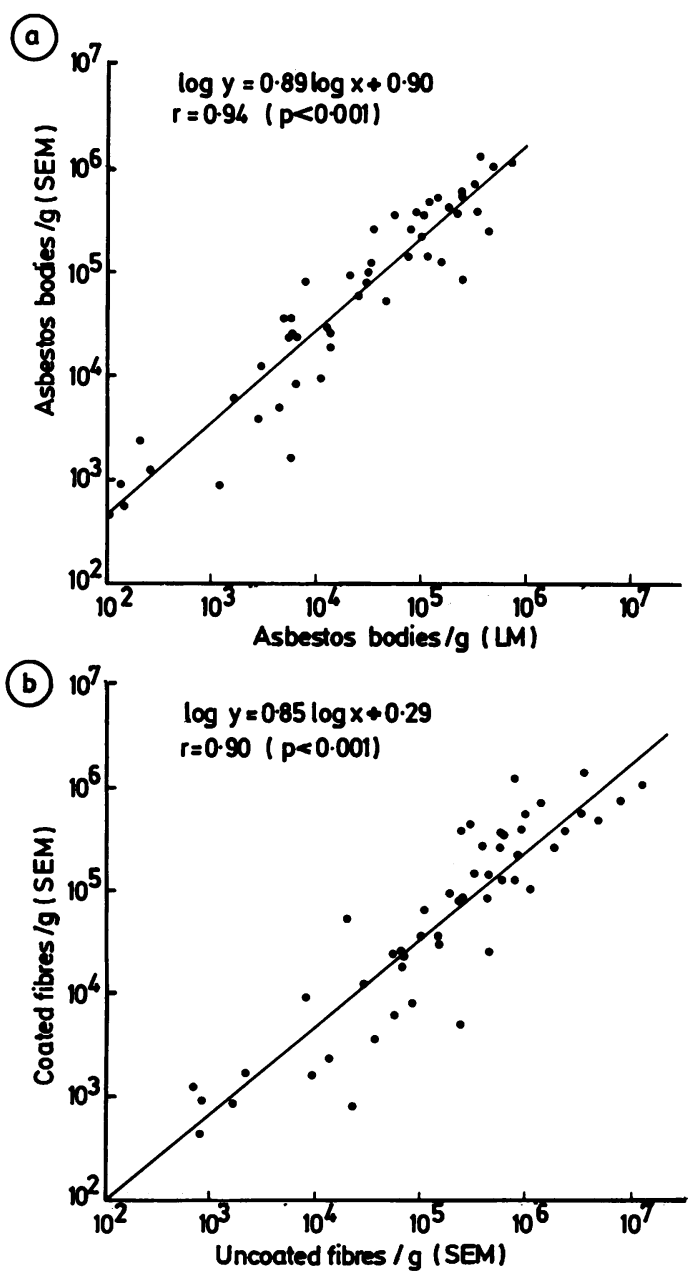

Fig 3 (a) Correlation between asbestos body counts by light and scanning electron microscopy in 50 cases of asbestos associated diseases. Each dot represents one case $(r=0.94, p<0.001)$. (b) Correlation between asbestos body and uncoated fibre counts by scanning electron microscopy $(r=0.90, p<0.001)$. 
of uncoated to coated fibres, whereas cases with sparsely coated bodies tended to have a higher ratio.

\section{CHEMICAL COMPOSITION OF FIBRES}

The results of energy dispersive $x$ ray analysis of 809 fibres from 57 cases are summarised in table 4 . Analysis of 407 asbestos body cores shows that $98.5 \%$ are in fact nucleated on asbestos, and non-asbestos cores were rare, being found in only one case. In this instance six fibres with a chemical composition of $\mathrm{Si}-\mathrm{Al}-\mathrm{K}-\mathrm{Ca}-\mathrm{Fe}-\mathrm{Mg}$ were identified as constituting the cores of thin, high aspect ratio coated fibres from an asbestos cement worker. The vast majority $(93.9 \%)$ of asbestos bodies were nucleated on commerical amphibole (amosite or crocidolite) cores, whereas $2.5 \%$ and $2.2 \%$ had cores of non-commercial amphiboles (anthophyllite, tremolite, or actinolite) and chrysotile, respectively. Analysis of 404 uncoated fibres $5 \mu \mathrm{m}$ or greater in length shows that most of these $(88.1 \%)$ are also asbestos, with $78.1 \%$ commercial amphiboles, $4.5 \%$ non-commercial amphiboles, and $5.5 \%$ chrysotile. In cases with high content of amphibole fibres $(100000$ or more per gram of wet lung) chrysotile fibres are difficult to identify by SEM. In cases with low amphibole content-for example, the four cases with idiopathic pulmonary fibrosis-a few fibres identified were more often chrysotile or non-asbestos fibres. The latter include fibreglass, talc, silica, rutile, kaolinite, mica, and assorted silicates not further classified (table 4).

\section{Discussion}

In the present study the asbestos content of lung tissue in patients with asbestosis, mesothelioma, and pleural plaques was found to correlate well with present concepts of the epidemiology of these diseases. Patients with asbestosis have the highest levels of exposure to asbestos, whereas mesothelioma (in the absence of asbestosis) can occur in individuals with much less exposure. ${ }^{12}$ The relatively greater asbestos content of the lung in asbestosis as compared with cases of mesothelioma is consistent with this observation. Similarly, parietal pleural plaques are the most common lesions observed in populations exposed to asbestos, ${ }^{1321}$ and in patients with plaques in the absence of asbestosis the asbestos content of lung is relatively low in this study and previous ones. ${ }^{22-24}$ Unilateral parietal pleural plaques may be related to asbestos exposure, but these lesions can also be related to infection or trauma. ${ }^{24}$ The asbestos body content of lung tissue tends to be much higher in patients who work directly with asbestos compared with manual labourers and "other" occupational groups, although there is considerable overlap among occupational categories. Individuals in the other occupational category with asbestos body content exceeding $100 \mathrm{ABs} / \mathrm{g}$ probably have remote, undetected prior exposure to asbestos. ${ }^{413}$

Previous studies have noted a correlation between the degree of interstitial fibrosis and the asbestos fibre count by phase contrast microscopy. ${ }^{2526}$ More recently Warnock et al examined this relation using transmission electron microscopy. ${ }^{27}$ Their data (table 2) ${ }^{27}$ show a fairly good correlation between the estimated degree of fibrosis and asbestos body and commercial amphibole content of lung tissue, but not for total fibre counts, non-commercial amphiboles, or chrysotile content. The results of our study, using scanning electron microsocopy and the asbestosis grading scheme of the Pneumoconiosis Committee of the College of American Pathologists and the National Institute for Occupational Safety and Health show a correlation between the severity of asbestosis and the total (coated and uncoated) fibre count $(r=0.57, p<0.05)$ and the uncoated fibre count $(\mathrm{r}=0.56, \mathrm{p}<0.05)$ for fibres $5 \mu \mathrm{m}$ or greater in length. ${ }^{11}$ Several studies have indicated that longer

Table 4 Energy dispersive $x$ ray analysis data on 809 fibres from 57 cases

\begin{tabular}{|c|c|c|c|c|c|c|c|}
\hline & No & & $\begin{array}{l}\text { Commercial } \\
\text { amphiboles }\end{array}$ & $\begin{array}{l}\text { Non-commercial } \\
\text { amphiboles }\end{array}$ & Chrysotile & Other* & Total \\
\hline Asbestosis & 27 & $\begin{array}{l}\text { C } \\
\text { UC }\end{array}$ & $\begin{array}{l}252 \\
195\end{array}$ & $\begin{array}{l}3 \\
1\end{array}$ & $\begin{array}{l}0 \\
0\end{array}$ & $\begin{array}{l}6 \\
3\end{array}$ & $\begin{array}{l}261 \\
199\end{array}$ \\
\hline Mesothelioma & 12 & C & $\begin{array}{l}64 \\
50\end{array}$ & 1 & 7 & 0 & 72 \\
\hline Parietal pleural plaques & 6 & $\begin{array}{l}\text { C } \\
\text { UC }\end{array}$ & $\begin{array}{l}50 \\
41 \\
26\end{array}$ & $\begin{array}{l}6 \\
5 \\
1\end{array}$ & $\begin{array}{l}9 \\
0 \\
0\end{array}$ & $\begin{array}{r}12 \\
0 \\
10\end{array}$ & $\begin{array}{l}77 \\
46 \\
37\end{array}$ \\
\hline Lung cancer & 8 & C & 23 & 1 & 2 & 0 & 26 \\
\hline Idiopathic pulmonary fibrosis & 4 & $\begin{array}{l}\text { UC } \\
\text { Un }\end{array}$ & $\begin{array}{l}42 \\
2\end{array}$ & $\begin{array}{l}5 \\
0 \\
5\end{array}$ & $\begin{array}{r}2 \\
0\end{array}$ & $\begin{array}{l}2 \\
0\end{array}$ & $\begin{array}{r}51 \\
2\end{array}$ \\
\hline Total & 57 & $\begin{array}{l}\text { UC } \\
\text { UC }\end{array}$ & $\begin{array}{c}1 \\
382 \\
314\end{array}$ & $\begin{array}{r}5 \\
10 \\
18\end{array}$ & $\begin{array}{r}11 \\
9 \\
22\end{array}$ & $\begin{array}{r}21 \\
6 \\
48\end{array}$ & $\begin{array}{r}38 \\
407 \\
402\end{array}$ \\
\hline
\end{tabular}

*Includes fibreglass (15), talc (6), silica (6), rutile (5), kaolinite (4), mica (1), Si-Al-Fe (4), Al-Fe (1), Mg-Al-Si (6), Si-Al-K-Ca-Fe-Mg (6). $\mathrm{C}=$ Coated; UC $=$ uncoated. 
fibres are more fibrogenic than shorter ones, ${ }^{28-30}$ and it is these longer fibres that are measured under the current regulatory standards. ${ }^{31}$ Although the degree of correlation in our study is less than impressive, it would probably improve with more extensive histological and mineralogical sampling of the lungs and the expression of the data as total lung burden rather than concentration. Accumulation of collagen and other cellular components as a result of the scarring process increases the weight of the lungs and hence dilutes the concentration of fibres in the parenchyma, a point often overlooked in dust analysis studies. ${ }^{32}$

An additional finding in our study was a correlation between the grade of asbestosis and smoking history in pack-years $(r=0.53, p<0.05)$. This observation has been noted previously in radiological studies, ${ }^{33}$ and it has been suggested that this is due to interference with dust clearance mechanisms by cigarette smoke. Our data, however, did not show a correlation between pack-years of smoking and uncoated fibre content of lung tissue $(n=19, r=0.28, p>0.05)$. The mechanism of interaction between asbestos and cigarette smoke in increasing interstitial fibrosis deserves further study.

Lung cancer occurred in 15 of the patients with asbestosis in our study. Among the patients with asbestosis, those with lung cancer were older (median age of $63 v 57$ ) and had a higher average cigarette consumption (mean of $48.8 v 29$ pack-years) than those without cancer. The latter observation was also noted in the study by Warnock et al. ${ }^{27}$ The histological patterns of lung cancer did not differ among patients with asbestosis, with increased asbestos content without asbestosis, or with normal asbestos content (table 4). This finding is in keeping with the observation of Ives et al that no specific histological pattern of lung cancer is associated with asbestos exposure. ${ }^{34}$ Although our study does not permit a calculation of the incidence of lung cancer in patients with asbestosis due to biases in referral of cases, it should be noted that other authors have reported that more than half the patients with asbestosis will develop lung cancer. ${ }^{35}$ In our experience this is much greater than the incidence of lung cancer in patients with idiopathic pulmonary fibrosis, and indeed only one case in ten with idiopathic pulmonary fibrosis in our study had lung cancer. Thus mechanisms other than the scarring process per se are probably operative in the pathogenesis of lung cancer in patients exposed to asbestos. ${ }^{36}$

Relatively few reports have dealt with the lung content of asbestos in patients with mesothelioma. Whitwell et al in a series of 100 patients with mesothelioma reported that $95 \%$ of those with asbestos induced mesotheliomas had over 50000 fibres/g of dried lung by phase contrast microscopy compared with only
$15 \%$ of the control series. ${ }^{26}$ In a study of 99 mesothelial tumours in North America McDonald et al noted equal numbers of chrysotile fibres in cases $v$ controls, whereas there were increased numbers of amphibole fibres by transmission electron microscopy in a greater percentage of cases compared with controls. ${ }^{37}$ More recently, Churg and Wiggs reported on numbers and sizes of fibres from the lungs of 10 patients who had an amphibole induced malignant pleural mesothelioma, ${ }^{38}$ and found an approximately 250-fold increase in commercial amphiboles by analytical transmission electron microscopy in the patients with mesothelioma compared with the general population. Two studies have reported data concerning asbestos fibre counts by SEM in patients with mesothelioma. ${ }^{2239}$ Gylseth et al found two million or more fibres per gram of dried lung in all 15 patients with mesothelioma studied. ${ }^{22}$ Friedrichs and Otto studied 34 cases of occupationally associated mesotheliomas, and found more than three times as many fibres in those with asbestosis than in those without. ${ }^{39}$

The present study shows that our patients with mesothelioma fall into three broad categories. Those who also have asbestosis have among the highest values of asbestos body and uncoated fibre counts we have observed. Those who do not have asbestosis but do have an occupational exposure history almost always have raised asbestos body counts and about $10 \%$ as many uncoated fibres greater than $5 \mu \mathrm{m}$ in length compared with cases of asbestosis. Those who have normal asbestos body counts do not have asbestosis and usually do not give a history of exposure to asbestos. Others have reported such cases and have attributed them as being "spontaneous" mesotheliomas. 263940 These cases with a lung asbestos content within the normal range and with no demonstrable occupational exposure to asbestos are probably non-asbestos related mesotheliomas and account for $20-30 \%$ of all cases. ${ }^{41}$ Alternatively, these cases may represent mesotheliomas in a susceptible host due to environmental rather than occupational asbestos exposure.

Several epidemiological studies have shown an association between exposure to asbestos and gastrointestinal carcinoma, ${ }^{2423}$ laryngeal carcinoma, ${ }^{2144}$ and haematopoietic malignances, ${ }^{20}$ although these $\sigma$ associations have not remained unchallenged. ${ }^{3145} \mathrm{~N}$ Analysis of the asbestos content of lung tissue in such N cases can document exposure but does not prove causation. None the less, it is of interest to examine lung tissue from individuals with such diseases and histor-

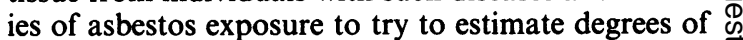
exposure. None of our cases with histologically : proved asbestosis had any of these neoplasms. Among our cases of pleural plaques, however, were 12 with one of these three categories of malignancy. The 12 
had a higher median asbestos body count than the remaining 21 with bilateral pleural plaques. These data suggest the possibility that these diseases may occur in individuals with moderate exposures to asbestos, and further studies are needed to examine this matter more fully.

The present study has dealt with the asbestos content of lung tissue in a series of patients with diseases that have been associated with exposure to asbestos. It is important to emphasise the value and the limitations of asbestos body quantification in these diseases. As has been noted by Churg, determination of asbestos body content is a relatively quick and easy procedure. $^{4}$ Bodies with the typical beaded configuration and a thin transparent central core are virtually always nucleated on asbestos fibres as shown by energy dispersive $x$ ray analysis and selected area electron diffraction. ${ }^{419}$ The vast majority are commercial amphiboles (amosite or crocidolite), both among individuals with asbestos associated diseases (table 4) and members of the general population, with the exception that non-commercial amphibole cores (tremolite or anthophyllite) are fairly common in women from the general population. ${ }^{46}$ Furthermore, it is primarily fibres $20 \mu \mathrm{m}$ or more in length that become coated. ${ }^{47}$ Although there are virtually always more uncoated than coated fibres by electron microscopy, the correlation between asbestos body counts and uncoated fibres $5 \mu \mathrm{m}$ or greater in length is excellent in the population we studied (fig 3 ). These findings are essentially indentical to those reported by Morgan and Holmes, who used phase contrast microscopy to count coated and uncoated fibres. ${ }^{48}$ Thus asbestos body content is a reasonably reliable marker for levels of long amphibole fibres. On the other hand, the correlation between asbestos body counts and concentration of chrysotile or noncommercial amphibole fibres is poor, ${ }^{49}$ the vast majority of these fibres being $5 \mu \mathrm{m}$ or less in length. Although occasional asbestos bodies with chrysotile fibres may be encountered (table 4), asbestos bodies give little or no indication of the chrysotile content of the lung. In the present study we did not evaluate the short fibres $(<5 \mu \mathrm{m})$ and thus cannot comment on their possible association with these diseases. The pathogenicity of such short fibres has been questioned, ${ }^{50}$ and their role (if any) in asbestos associated diseases has yet to be defined. ${ }^{31}$

We gratefully acknowledge the following physicians who referred case material for study: Doctors $\mathbf{J}$ Adams, Chattanooga, TN; F B Askin, Chapel Hill, NC; A Churg, Vancouver, BC; D Dail, Seattle, WA; J R Edgar, Savannah, GA; J C Franco, Fayetteville, NC; B Gylseth, Oslo, Norway; S Harris, Greensboro, NC; W B Helwig, J C Maddox, J Legier, J C Davis,
Jr, and F Q Wingfield, Newport News, VA; R A Heyer, Charlotte, NC; R V Joel, Jacksonville, FL; E Kagan, Washington, DC; D Kaminsky, Rancho Mirage, CA; Marie-Claire Marroum, Charlotte, NC; C T O'Connell, Hampton, VA; J H Riddick, Jr, Chesapeake, VA; W Stopford, Durham, NC; P Warga, Salisbury, NC; B Woodard, Anderson, SC; and Elsa Yap, Concord, NC. Dr R T Vollmer helped with the statistical analyses and Diane Evans provided expert help in preparing the manuscript for publication.

Requests for reprints to: Victor L Roggli, MD, Department of Pathology, Post Office Box 3712, Duke University Medical Center, Durham, NC 27710, USA.

\section{References}

${ }^{1}$ Becklake MR. Asbestos-related diseases of the lung and other organs: their epidemiology and implications for clinical practice. Am Rev Respir Dis 1976;114:187-227.

${ }^{2}$ Selikoff IJ, Lee DHK. Asbestos and disease. New York: Academic Press, 1978.

${ }^{3}$ Wagner JC, Sleggs CA, Marchand P. Diffuse pleural mesothelioma and asbestos exposure in the North Western Cape province. $\mathrm{Br}$ $J$ Ind Med 1960;17:260-71.

${ }^{4}$ Churg AM, Warnock ML. Asbestos and other ferruginous bodies: their formation and clinical significance. Am $J$ Pathol 1981;102:447-56.

${ }^{5}$ Smith MJ, Naylor B. A method of extracting ferruginous bodies from sputum and pulmonary tissue. Am J Clin Pathol 1972;58:250-4.

${ }^{6}$ Roggli VL, Greenberg SD, Seitzman LH, et al. Pulmonary fibrosis, carcinoma, and ferruginous body counts in amosite asbestos workers: a study of six cases. Am J Clin Pathol 1980;73:496-503.

${ }^{7}$ Churg A, Warnock ML. Correlation of quantitative asbestos body counts and occupation in urban patients. Arch Pathol Lab Med 1977;101:629-34.

${ }^{8}$ Bignon J, Goni J, Bonnaud G, Jaurand MC, Dufour G, Pinchon MC. Incidence of pulmonary ferruginous bodies in France. Environ Res 1970;3:430-42.

9 Bhagavan BS, Koss LG. Secular trends in prevalence and concentration of pulmonary asbestos bodies-1940 to 1972: a necropsy study. Arch Pathol Lab Med 1976;100:539-41.

${ }^{10}$ Rosen P, Melamed M, Savino A. The "ferruginous body" content of lung tissue: a quantitative study of eighty-six patients. Acta Cytol 1972;16:207-11.

${ }^{11}$ Craighead JE, Abraham JL, Churg A, et al. The pathology of asbestos-associated diseases of the lungs and pleural cavities: diagnostic criteria and proposed grading schema. (Report of the Pneumoconiosis Committee of the College of American Pathologists and the National Institute for Occupational Safety and Health.) Arch Pathol Lab Med 1982;106:544-96.

12 Roggli VL, McGavran MH, Subach J, Sybers HD, Greenberg SD. Pulmonary asbestos body content and electron probe analysis of asbestos body cores in patients with mesothelioma: a study of 25 cases. Cancer 1982;50:2423-32.

${ }^{13}$ Wain SL, Roggli VL, Foster WL. Parietal pleural plaques, asbestos bodies, and neoplasia: a clinical, pathological, and radiographic correlation of 25 consecutive cases. Chest 1984;86:707-13.

${ }^{14}$ Meurman L. Asbestos bodies and pleural plaques in a Finnish series of autopsy cases. Acta Pathol Microbiol Immunol Scand [Suppl] 1966;181:1-107.

${ }^{15}$ World Health Organisation. The World Health Organisation his- 
tologic typing of lung tumours, 2nd ed. Am J Clin Pathol 1982;77:123-36.

${ }^{16}$ Roggli VL, Shelburne JD. New concepts in the diagnosis of mineral pneumoconioses. Seminars in Respiratory Medicine 1982;4:138-48.

${ }^{17}$ Williams MG, Dodson RF, Corn C, Hurst GA. A procedure for the isolation of amosite asbestos and ferruginous bodies from lung tissue and sputum. $J$ Toxicol Environ Health 1982;10:627-38.

${ }^{18}$ Roggli VL, Brody AR. Changes in numbers and dimensions of chrysotile asbestos fibers in lungs of rats following short-term exposure. Exp Lung Res 1984;7:133-47.

${ }^{19}$ Churg A, Warnock ML, Green N. Analysis of the cores of ferruginous (asbestos) bodies from the general population. II. True asbestos bodies and pseudoasbestos bodies. Lab Invest 1979;40:31-8.

${ }^{20}$ Kagan E, Jacobson RJ. Lymphoid and plasma cell malignances: asbestos-related disorders of long latency. Am J Clin Pathol 1983;80:14-20.

${ }^{21}$ Hillerdal G. Pleural plaques: occurrence, exposure to asbestos, and clinical importance. Uppsala: Offsetcenter ab, 1980.

${ }^{22}$ Gylseth B, Mowe G, Skaug V, Wannag A. Inorganic fibers in lung tissue from patients with pleural plaques or malignant mesothelioma. Scand J Work Environ Health 1981;7:109-13.

${ }^{23}$ Warnock ML, Prescott BT, Kuwahara TJ. Numbers and types of asbestos fibers in subjects with pleural plaques. Am J Pathol 1982;109:37-46.

${ }^{24}$ Churg A. Asbestos fibers and pleural plaques in a general autopsy population. Am J Pathol 1982;109:88-96.

${ }^{25}$ Ashcroft T, Heppleston AG. The optical and electron microscopic determination of pulmonary asbestos fibre concentration and its relation to the human pathological reaction. J Clin Pathol 1973;26:224-34.

${ }^{26}$ Whitwell F, Scott J, Grimshaw M. Relationship between occupations and asbestos-fibre content of the lungs in patients with pleural mesothelioma, lung cancer, and other diseases. Tho$\operatorname{rax}$ 1977;32:377-86.

${ }^{27}$ Warnock ML, Kuwahara TJ, Wolery G. The relation of asbestos burden to asbestosis and lung cancer. Pathol Annu 1983;18:109-45, part 2.

${ }^{28}$ Davis JMG, Beckett ST, Bolton RE, Collings P, Middleton AP. Mass and number of fibres in the pathogenesis of asbestosrelated lung disease in rats. Br J Cancer 1978;37:673-88.

${ }^{29}$ Vorwald AJ, Durkan TM, Pratt PC. Experimental studies of asbestosis. Arch Ind Hyg Occup Med 1951;3:1-43.

${ }^{30}$ Wright GW, Kuschner M. The influence of varying lengths of glass and asbestos fibres on tissue response in guinea pigs. In: Walton WH, ed. Inhaled particles IV. Oxford: Pergammon Press, 1977:455-74.

${ }^{31}$ Craighead JE, Mossman BT. The pathogenesis of asbestosassociated disease. $N$ Engl J Med 1982;306:1446-55.

${ }^{32}$ Pratt PC. Role of silica in progressive massive fibrosis in coal workers' pneumoconiosis. Arch Environ Health 1968;16:734-7

${ }^{33}$ McMillan GHG, Pethybridge RJ, Sheers G. Effect of smoking on: attack rates of pulmonary and pleural lesions related to exposure to asbestos dust. $\mathrm{Br} J$ Ind $\mathrm{Med}$ 1980;37:268-72.

${ }^{34}$ Ives JC, Buffler PA, Greenberg SD. Environmental association? and histologic patterns of carcinoma of the lung: the challenge

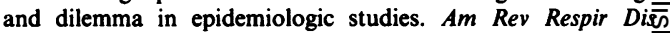
1983;128:195-209.

${ }^{35}$ Buchanan WD. Asbestosis and primary intrathoracic neoplasms Ann NY Acad Sci 1965;132:507-18.

${ }^{36}$ Mossman BT, Craighead JE. Mechanisms of asbestos carcinogenesis. Environ Res 1981;25:269-80.

${ }^{37}$ McDonald AD, McDonald JC, Pooley FD. Mineral fibre conteniof lung in mesothelial tumours in North America. Ann Occup $\vec{\omega}$ Hyg 1982;26:417-22.

${ }^{38}$ Churg A, Wiggs B. Fiber size and number in amphibole asbestos. induced mesothelioma. Am J Pathol 1984;115:437-42.

${ }^{39}$ Friedrichs $\mathrm{KH}$, Otto $\mathrm{H}$. Fibers in human lung dust samples: scanning electron microscope study. Am Ind Hyg Assoc $\overrightarrow{\not t}$ 1981;42:150-6.

${ }^{40}$ Peterson JT, Greenberg SD, Buffler PA. Non-asbestos-related ${ }_{\infty}$ malignant mesothelioma: a review. Cancer 1984;54:951-60.

${ }^{41}$ Chahinian AP, Pajak TF, Holland JF, Norton L, Ambinder RM은 Mandel EM. Diffuse malignant mesothelioma: prospective evaluation of 69 patients. Ann Intern Med 1982;96:746-55.

${ }^{42}$ Selikoff IJ, Hammond EC, Seidman H. Mortality experience of insulation workers in the United States and Canada, 1943-1976. In: Selikoff IJ, Hammond EC, eds. Health hazards and asbestos exposure. Ann NY Acad Sci 1979;330:91-116.

${ }^{43}$ Finkelstein MM. Mortality among employees of an Ontario $\overrightarrow{0}$ asbestos-cement factory. Am Rev Respir Dis 1984;129:754-61.

${ }^{44}$ Stell PM, McGill T. Asbestos and laryngeal carcinoma. Lancet 1973;ii:416-7.

${ }^{45}$ McCullagh SF, Aresini G, Browne K, et al. Criteria for the diagno sis of asbestosis and considerations in the attribution of lung cancer and mesothelioma to asbestos exposure. Int Arch Occup Environ Health 1982;49:357-61.

${ }^{46}$ Churg A, Warnock ML. Analysis of the cores of ferruginous (asbestos) bodies from the general population. III. Patients with. environmental exposure. Lab Invest 1979;40:622-6.

${ }^{47}$ Morgan A, Holmes A. Concentrations and dimensions of coated and uncoated asbestos fibres in the human lung. $\mathrm{Br} J$ Ind Med 1980;37:25-32.

${ }^{48}$ Morgan A, Holmes A. Distribution and characteristics of amphibole asbestos fibres, measured with the light microscope, in the left lung of an insulation worker. Br J Ind Med 1983;40:45-50

${ }^{49}$ Warnock ML, Prescott BT, Kuwahara TJ. Correlation of asbestos bodies and fibers in lungs of subjects with and without asbestosis In: Johari O, Becker RP, eds. Scanning electron microscopy II:AMF O'Hare, III: SEM, Inc, 1982:845-57.

${ }^{50} \mathrm{Gross}$ P. Is short-fibered asbestos dust a biological hazard? Arch Environ Health 1974;29:115-7. 